\title{
Social Movement Literature and U.S. Labour: A Reassessment
}

\author{
KEITH MANN \\ Cardinal Stritch University ${ }^{1}$, USA
}

ABSTRACT Largely due to its conservative profile at the time, the U.S. labour movement was largely absent from modern social movement literature as it developed in response to the new social movements of the 1960s and 1970s. Recent labour mobilizations such as the Wisconsin uprising and the Chicago Teachers'strike have been part of the current international cycle of protest that includes the Arab Spring, the antiausterity movements in Greece and Spain, and Occupy Wall Street. These struggles suggest that a new labour movement is emerging that shares many common features with new social movements. This article offers a general analysis of these and other contemporary labour struggles in light of contemporary modern social movement literature. It also critically reviews assumptions about the labour movement of the 1960s and 1970s and reexamines several social movement concepts.

Most commentary on the contemporary U.S. labour movement focuses on the decades-long decline of union strength in terms of membership, power, and influence. Reflection on labour protest tends to emphasize the defensive nature of strikes and other forms of collective action. But a close look at labour struggles over the last five years suggests that a new labour movement is emerging that differs in many ways from the labour movement of the last half century. This emerging labour movement begs close analysis from the perspective of social movement literature. Yet, those looking to existing social movement literature for cues on how to study contemporary labour as a social movement will find that very little of the considerable amount of social movement literature produced over the last half century has been devoted to labour. Indeed, the labour movement has always held a peculiar position in 
modern social movement literature. Implicitly and occasionally explicitly, labour has been almost the anti-social movement, the counter example to the "real" social movements that arose in the second half of the twentieth century - the civil rights, women's, anti-war, gay and lesbian, and other movements. In social movement literature, labour is the quintessential "old social movement" as opposed to the "new social movements" that began with the post-war U.S. civil rights movement (Touraine, 1971; Calhoun, 1993; Buechler, 2011).

This article reexamines the labour movement as a social movement. It explores how assumptions both accurate and inaccurate about labour shaped modern social movement literature. It also offers a general analysis of recent labour struggles from the point of view of modern social movement literature. Finally, it suggests some implications of these movements for social movement theory and research. We begin by briefly reviewing aspects of the labour movement from the 1930s to the time of the emergence of contemporary social movement theory in the 1960s.

\section{From Insurgency to Complacency}

The 1930s were in many ways one of labour's golden ages. The 1920s had been a time of repression and decline. Unions declined in strength relative to the period before World War I in the face of ferocious repression against labour radicals and union organizers while Taylorist rationalizing and speedups made factory life miserable and dangerous. But in the 1930s, industrial union organizing drives tapped into the anger, energy, and creativity of millions of un- and semiskilled workers. The 1930s labour movement bore the characteristics of what social movement theory would later describe as an "emerging" social movement. The mass strikes, including sit-down strikes of the mid-1930s in auto plants and also in department stores and textile mills, areas of female labour, demonstrated the determination and creativity of these workers. By reaching out to unorganized and unemployed workers, the unemployed movements of the great Depression reflected the broad social concerns and vision of the labour movement (Piven \& Cloward, 1977). Militant, mass labour protest continued into the 1940s and 1950s, exemplified by bitter coal strikes in the 1940s and steel strikes including the months-long steel strike begun in July, 1959 which involved 500,000 strikers.

The spectacular victories of union organizing drives, the passage of the National Labor Relations Act (NLRA), also known as the Wagner Act in 1937, and the formation of the New Deal coalition made labour a player in national politics. But these same victories also helped produce a bloated, conservative union bureaucracy, increasingly distant from the rank and file, while the institutionalization of work place labour relations had a demobilizing effect on the mass of rank-and-file workers. Eventually, a dynamic labour movement was transformed into what social movement literature would later refer to as a "routinized" social movement. 


\section{Worlds Apart: The Labour and Civil Rights Movement}

While the world watched spectacular actions by the post-war civil rights movement in the name of basic human rights, the labour movement seemed to lapse into a slumber. To many observers, the labour movement of the $1960 \mathrm{~s}$ seemed stodgy, conservative, and narrow in scope, focus, and composition. These were the years when AFL-CIO head, George Meany, declared with pride that he had never walked a picket line, when New York City hardhats attacked antiwar demonstrators, and corruption and mob influence in unions like the Teamsters sent top labour officials to prison. No post-war labour leader ever came close to enjoying the moral stature of a Martin Luther King or even a Gloria Steinem or a Betty Friedan. Women and minorities held few positions in the often well paid union officialdom. In fact, the latter had to wage concerted campaigns, including recourse to legal action, to gain access to union posts (Needleman, 2003). The success of large unions in manufacturing like auto, steel, rubber, etc. in securing favorable contracts at the bargaining table, without recourse to mass collective action like strikes and demonstrations, and their studied avoidance of criticism of U.S. foreign policy and reluctance to champion broader social issues, made the labour movement seem worlds apart from authentic social movements and unionized workers seemed to be an increasingly privileged layer of the working class.

\section{Missing Identity}

The prominence of identity issues in the civil rights, women's and gay and lesbian movements also seemed to remove labour from consideration as a bona fide social movement. Given the dominant culture's erasure of the working class as a distinct social category, a reflection of the rampant individualist impulse in U.S. society and the cultural hegemony of the employing class, post-war representations of labour offered by the labour movement and its observers did not underscore the working class as a social, political, or cultural category, in spite of a manufacturing sector that employed a full $35 \%$ of the work force in the immediate post-war world. In traditional Marxist terms, the working class seemed to exist "in itself" but not "for itself" at a time when Black and women's consciousness-raising efforts were integral to the internal life and public demands of the civil rights and women's movements.

Much of this attests to the integrative power of U.S. capitalism in the postwar boom. The combination of significant wage and benefit concessions by industrial capital to powerful industrial unions on the one hand, and red baiting and witch hunting on the other, gave a section of the white, male working class unprecedented material gains while their unions became conservative, fossilized, and undemocratic (Pries, 1972). One of the consequences of the regularization of industrial conflict brought about through the National Labor Relations Act (NLRA) was a routinization of shop floor industrial relations. Over time, the masses of rank-and-file workers became demobilized and 
out of touch with the active participation of the 1930s, while movement organizations' (SMOs) unions became routinized and bureaucratized (Dobbs, 1977; Meyer, 1992; Preis, 1972).

The marginalization of labour from the social movement research agenda also reflected - and was given theoretical justification by - the view that the working class had lost its sociological cohesion as a social group in the new post-war "post-industrial society." (Gorz, 1980; Touraine, 1971). By the 1980 s, social and labour historians influenced by postmodern social theory also began to challenge the existence of class in general (Jones, 1983; Scott, 1988).

This was the backdrop to the development of modern social movement theory and research. By 1970 relative deprivation theory had become a well-established theory, perhaps the first innovation in social science theory developed in response to the social movements of the time. During the 1970s, resource mobilization acquired state-of-the-art status largely supplanting relative deprivation as the leading explanatory device to account for the emergence of social movements. Some of the best social movement literature, such as Doug McAdam's Freedom Summer, involved sustained research into specific social movements (McAdam, 1998). But given the reality and perceptions of the labour movement at the time, labour as a social movement received little attention from social movement scholars.

\section{Social Unionism and Wildcat Strikes}

But this view of labour was far from complete. While it did accurately describe the trajectory of the union bureaucracy, there was simultaneously another side of the labour movement. Although the "business unionism" of big industrial unions in the manufacturing sector and in the building trades seemed to represent labour as a whole, unions like the United Farm Workers (UFW), continued the tradition of rank-and-file mobilization and social unionism. In doing so, they resembled the newly emerging social movements of the 1950s, 60s, and 70s. The UFW's reliance on a community-oriented strategy, the combined character of the organization as both a labour and civil rights organization at a time when the Chicano rights movement was in full swing, and its use of strategies and tactics borrowed directly from the civil rights movement made the UFW and the campaigns it championed the center of a new social movement. The grape boycott it called in the 1970s reached well beyond agricultural labour and Mexican-American and Mexican immigrant communities. The struggles of the UFW and their high profile leader, Caesar Chavez, did not of course escape the view of social movement scholars. But they were not seen primarily as labour struggles (Shaw, 2010).

Although far less well known than the UFW campaigns, there was significant rank-and-file labour militancy during those years. Rick Fantasia and Judith Stepan-Norris (2004) have offered evidence of an impressive number of wildcat strikes carried out without the approval, and often 
against the wishes, of the official union leadership. Their limited size and short duration put them under the radar screen of government statisticians. Extrapolating from data collected on strikes at the Westdale Steel Plant for the years 1944-1958, they conclude that from 1961 to 1977 wildcat strikes accounted for 47 to 66 percent of all strikes (p. 568).

Many of these strikes were launched in response to Taylorist-like speedup drives whose full force fell inordinately on Black and women workers who were overwhelmingly assigned to the unskilled and semiskilled sectors where Taylorist speed-up drives were rampant. According to the militant rank-and-file Black worker's organization, the Dodge Revolutionary Union Movement (DRUM), only 10\% of skilled positions were held by Black workers. DRUMS's newsletter chronicled in detail how Black unskilled and semiskilled workers were treated markedly worse by management and foremen than their white counterparts (DRUM, Volume 1, Number 2). In 1968, the organization led wild cat strikes at Chrysler.

DRUM also challenged the conservative UAW leadership that had failed to integrate Black workers into union structures (Geschwender, 1977; Glaberman, 1969). One of the most significant rank-and-file challenges against conservative, bureaucratic unionism was the formation of the Teamsters for a Democratic Union (TDU) in the 1970s in the notoriously undemocratic Teamsters union (Brenner, Brenner, \& Winslow, 2010; LaBotz, 1991).

In Europe, bursts of rank-and-file militancy and mass mobilization like the 1960-1961 general strike in Belgium, the June 1968 strikes in France, and the Italian wave of strikes in 1969 known as the autonno caldo made European labour relations far more turbulent than in the United States. The differences between the European and U.S. scene reflected in part the different balance of forces between labour and capital in Europe and the United States. A powerful U.S. capital class was able to take advantage of its dominant position in the post-war capitalist world to offer concessions in return for labour peace. European employers lacked this marge de maneauvre. Recent scholarship has also spotlighted a wave of rank-and-file militancy in France in the years following the May-June 1968 upsurge involving wildcat strikes and the use of militant tactics like sequestration (Mann, 2011; Vigna, 2007).

In addition to the bureaucratization and routinization of the labour movement, and the low profile of rank-and-file struggles, Fantasia and Stepan-Norris (2004) offer another reason why labour has been marginalized in social movement literature. They point out that many social movement scholars have been "predisposed by their own biographical experiences of social movement activism to study those movements that are similar to those in which they have worked or those that have played a role in the development of their own intellectual stance and career trajectory, as well those movements that embody their own political values (p. 556)." In other words, many social movement scholars of the time had been involved with the civil rights, women's, antiwar, gay and lesbian, and other struggles but had little connection to the organized labour movement. As university 
students living on college campuses, and then as professors, they were far removed from labour struggles. Many were of middle class origin, isolating them further from proletarian lives and struggles.

Behind these developments were important changes in the composition of the working class. Women's work force participation has steadily risen both in real numbers and as a percentage of the labour force since at least the 1970s. In 1970, 31,543,000 women (as opposed to 51,228,000 men) participated in the paid work force, representing 38\% of the work force. By 2012 women represented $47 \%$ of the work force. Women, along with immigrants and

Table 1

\begin{tabular}{|c|c|c|c|c|}
\hline \multicolumn{5}{|c|}{ Civilian labour force by sex, 1970-2012 } \\
\hline & Number (in thousands) & \multicolumn{1}{|c|}{ Percent of the labour force } \\
\hline Year & Women & Men & Women & Men \\
\hline $\mathbf{1 9 7 0}$ & 31,543 & 51,228 & 0.38 & 0.62 \\
\hline $\mathbf{1 9 8 0}$ & 45,487 & 61,453 & 0.43 & 0.57 \\
\hline $\mathbf{1 9 9 0}$ & 56,829 & 69,011 & 0.45 & 0.55 \\
\hline $\mathbf{2 0 0 0}$ & 66,303 & 76,280 & 0.47 & 0.53 \\
\hline $\mathbf{2 0 1 2}$ & 72,648 & 82,327 & 0.47 & 0.53 \\
\hline
\end{tabular}

Source: Bureau of Labor Statistics (BLS), Current Population Survey (CPS)/ Graph by the Women's Bureau, U.S. Department of Labor

people of color were overwhelmingly concentrated in low-skill, lowwage jobs, which lacked health insurance and other benefits and were often dangerous as well. So the dominant view of labour as an old social movement, defined as a conservative, routinized SMO, is largely correct as a description of the labour bureaucracy and the general dominant, public image of labour. But, at the same time, rank-and-file collective action and social justice unionism which operated on a deeper, less publicized and officially documented level displayed many of the features found in the new social movements and highlighted in social movement theory and research. But the dominant view of labour as an old social movement served to establish a sharp division between old and new, which served to remove labour from the social movement research agenda.

\section{Contemporary Labour and the International Cycle of Protest}

Beginning in 2010, a wave of protests erupted, including the Arab Spring, the upheavals in Greece and Spain, the Wisconsin Uprising, and the Occupy Wall Street movement (Buhle \& Buhle, 2011; Yates, 2010). Labour struggles 
have been prominent. In the fall of 2010, unions in France launched mass protests against the Sarkozy government's move to raise the retirement age. The organized labour movement has been marginalized in the Greek and Spanish movements protests due to the ties between the major union confederations and socialist parties who advocate and implement neo-liberal austerity policies. In both countries millions of young workers, including many with college degrees, have never held full-time jobs, and therefore have never been union members. But the Greek and Spanish movements are labour protest due to their overwhelming popular nature as movements embodying much of civil society against deep austerity drives. In both countries, the organized labor movement has fought to be relevant. While the urban protests in Egypt gathered most of the attention in the uprisings that forced Mubarak out of office in February, 2011 and then Morsi in July, 2013, the backdrop of the movement had been thousands of labour strikes throughout the country. It has been argued that the mass strikes of February 9, 2011 were the decisive blows to the Mubarak regime (Hartshorn, 2013). Together, these various struggles conform closely to what social movement scholar Sidney Tarrow has called a cycle of protest (Tarrow, 1994). The basic features of a cycle of protest according to Tarrow involve a

\footnotetext{
phase of heightened conflict and tension across the social system that includes: a rapid diffusion of collective action from more mobilized to less mobilized sectors; a quickened pace of innovation in the forms of contention; new or transformed collective action frames; a combination of organized and unorganized participation; and sequences of intensified interaction between challengers and authorities which can end in reform, repression and sometimes revolution. (p. 153)
}

Although space limitations here preclude a detailed, point-by-point application of these features to contemporary struggles, the general affinity between these features of a cycle of protest and the protests that emerged since 2010 should be evident.

\section{Contemporary Labour as a Social Movement}

In the US, the current cycle of labour protest has been going on long enough to meet the "sustained" requirement that Charles Tilly and Lesley Wood (2009) argue necessary for a movement to qualify as a social movement. The current cycle of labour protest involves three arenas of collective action:

1. A series of rank-and-file insurgencies against conservative leaderships in the name of union democracy and militancy (Brenner, 2013).

2. Public sector strikes in Wisconsin in February-March 2011, and the Chicago Teachers strike in September, 2012. It also includes the worker mobilizations in Michigan and Indiana against the passage of "right to work" legislation. 
3. Demonstrations and strikes by low-wage undocumented workers whose struggles have combined immigration and labour issues. These include the mobilization of immigrant communities such as the Los Angeles janitor's strike, the "Day without Latinos" May day cerebration in 2006, and most recently the successful efforts of Mexican immigrant car wash workers, the Washeros, in winning union recognition. These also include strikes and union organizing drives at powerful low-wage employers like Wal-Mart and McDonald's.

Although the focus here is on events since 2010, the roots of the current revival of social movement unionism can be traced back to the 1990s when unions like the Service Employees International Union (SEIU), the Hotel and Restaurant Employees International Union (HERE), and the textile union UNITE launched bold and often successful organizing drives against powerful employers. The labour forces in these low wage service sectors were overwhelmingly immigrant, female, and people of color, groups which bureaucratic unions had long considered unorganizable. In their 2004 book, Hard Work, Rick Fantasia and Kim Voss identified a series of practices in these campaigns that contrasted sharply with those of business unionism (Fanstasia \& Voss, 2014, chapter 4). These included innovative organizing campaigns and a strong dose of social justice unionism.

An analysis of these developments suggests that the current cycle of labour protest in the US resembles in many ways the new social movements of the 1950 s onward. At the same time they also present challenges to contemporary social movement wisdom, which in turn calls for updates of, and revisions to that literature.

The next section provides an overview of the current cycle of labour protest through the lens of established concepts within social movement literature, drawing heavily from the work of Charles Tilly and his colleagues. The concepts and theories used to describe and analyze these movements are:

- WUNC performances. These are worthiness, unity, numbers, and commitment. Social movements display these.

- Repertoires of Collection Action. These refer to the tactics used by social movement actors. Tilly and Wood (2009) see them developing in their modern form from the late $18^{\text {th }}$ century onwards.

- Political Process theory refers to the connection between social movements and institutional politics.

In the US, the Wisconsin uprising looked much more like a 1930s rankand-file labour upheaval than the routinized, bureaucratically controlled labour actions of recent decades. The revolt in early 2011 against Republican governor Scott Walker's 'budget repair" bill, which eliminated collective bargaining in Wisconsin for public sector workers, demonstrated many of these features. Far from the routine, well-orchestrated rallies typically organized by the union officialdom, this struggle was arguably as close to an 
example of spontaneous collective action as possible, and it displayed classic examples of the repertoire of collective action. Protestors flocked to Madison immediately following news reports of the introduction of the bill. Hundreds occupied the Capitol building itself, sleeping on its marble floors for days on end. Noisy and spirited mass marches and rallies were held nearly daily for six weeks. The marches featured the display of banners and signs, mostly handmade, the chanting of slogans, and the wearing of badges. The breadth, scope, sustained militancy, and overall grassroots character of the uprising was clearly more reminiscent of 1930s style labour militancy and other familiar and recent social movements than the stale, top-down routinized labour actions seen in much of the post-war period. In the days and weeks that followed, the local and national union bureaucracy scrambled to assume control of the movement. National union staffers arrived and rented office space in front of the Capitol and the marching route. The sea of hand-written signs and banners gradually mingled with professionally produced signs and banners, courtesy of the AFL-CIO.

The Wisconsin Uprising differed in other ways from labour protest of the last half century. Although few journalistic observers seemed to notice, the Madison uprising was largely a women's movement; teachers were the largest group of affected public sector workers, and seventy-five percent of these are women. The Chicago Teachers' strike was not only a largely female action; it also featured a large percentage of people of color, symbolized by Karen Lewis, an African American woman who became union president with support from the reform caucus, CORE. Given trends in the workforce as a whole, there is every reason to expect that the new, emerging labour movement will evince a profile quite different from the White, native-born, male-dominated labour movement of the past.

\section{Contemporary Labour and WUNC Performances}

Both the Wisconsin Uprising and the Chicago Teachers' strike embodied many classic features highlighted in social movement literature. Both illustrate Charles Tilly's WUNC performance model (worthiness, unity, numbers, and commitment). Regarding worthiness, the strikers, largely teachers, portrayed themselves as community-minded citizens who work under difficult circumstances to educate disadvantaged children. The display of picket lines and the wearing of t-shirts were powerful examples of the unity reflected as was the success in winning huge majorities voting in favor of the strike. Rallies were attended by large numbers of teachers and supporting parents and students. The commitment of the strikers was shown over a long period of organizing as was the willingness of teachers to take on a powerful urban political machine with strong ties to the Obama administration. Like the Wisconsin uprising the teachers were largely women, as was their leader Karen Lewis. 


\section{Universalistic Demands}

As we have seen, the largely exclusive focus on wage, benefit, and job protection issues by the labour movement for much of the post-World War II period helped conservatives paint it as a narrow "special interest," a far cry from the broad progressive social force it was in earlier times, and helped to exclude it from the social movement research agenda. The contemporary labour movement, however, has raised demands that are pitched in the type of broad, universalistic terms that have always impressed social movement scholars as emblematic of authentic social movement master framing. The struggle against the Walker law was pitched in terms of social rights such as collective bargaining and universal principles such as democracy, as well as wages, benefits, and working conditions, in similar ways that other social movements have framed their struggles. The Madison protesters quickly latched onto one of the main master frames of the contemporary international cycle of protest, Democracy. One of the main slogans chanted during the demonstrations was "This is what democracy looks like." First chanted during the 1999 protests against the WTO in Seattle, the slogan took on special force as protestors linked their struggle to the emerging Arab Spring. Theirs was a radical, grassroots, bottom-up democracy.

The Chicago teachers strike also was framed in terms beyond salaries, benefits, and working conditions. The teachers' union conducted their struggle in words and deeds as much as a fight for poor, minority children, their families and communities as a fight to defend their interests as employees. The union forged durable alliances with community groups which were approached as partners. The union "was upfront about its view that treatment of Chicago students amounted to institutional racism" (Bradbury, Brenner, Brown, Slaughter, \& Winslow, 2014, p. 80). Under its new leadership, the CTU launched a campaign against banks like the Bank of America, whose foreclosures of homes in working class, poor, and minority neighborhoods have had a "devastating impact" (Bartlett, 2012, p. 7) on those communities, in part because foreclosures lead to reduced tax revenues for school budgets. Some contemporary labour struggles are deeply connected to immigration issues and struggles, clearly a form of social justice unionism. These add identity issues to the other classic social movement features seen in Wisconsin and Chicago.

\section{Grass Roots Union Organizing}

An unintended consequence of the assault on unions and collective bargaining has been a return to 1930 s-style grass roots union organizing. In Wisconsin nearly every teachers' union local in the first elections retained certification and collected voluntary dues through the type of one-on-one organizing that faded away with automatic dues check offs and routinized grievance procedures. There is also evidence that this is occurring in Michigan following the enactment of "right to work" legislation in that state. 
The contemporary cycle of labour protest qualifies, therefore, as a social movement in the sense that U.S. and, to an extent, European social movement literature has defined new social movements. At the same time, however, a close look at this movement reveals processes that are not completely explained by social movement literature. These include the relationship between existing bureaucratic SMO structures, mass insurgent groups, and mass rank-and-file mobilization, and the utility of the terms "old" and "new" social movements.

\section{"Old" versus "New": A useful distinction?}

Among European social movement scholars, the notion of an "old" and "new" social movement as staked out by Alain Touraine (Wievorka, 2012) focuses mostly on the types of demands the movement raises. Old social movements like labour focused on the material issues of wages, benefits, and working conditions, as opposed to the broader, more universalistic concerns that animate new social movements. In the US, scholars tend to define old and new social movements more by their forms of collective action and degrees of grass roots participation. We have seen in the above review of current labour mobilization that recent labour protest qualifies as a social movement and shares many features with the new social movements of the last few decades. Indeed, scholars such as Craig Calhoun, Marco Guigni and Nina Eggert have found the distinction between old and new social movements increasingly less satisfying. With the European labour movement in mind, Guigni and Eggert see a "homogenization" of the two types (Calhoun, 1993; Eggert \& Guigni, 2012). Bruce Spencer sees the distinction as problematic as well. He argues that the Canadian labour movement has adopted social movement strategies that bear close resemblance to new social movements (Spencer, 1995). Should social movement scholars view recent labour protests as the latest emergence of a new social movement along the lines that this has been understood by modern social movement literature? It might appear so, given the evidence. However, a close look at the internal dynamics of entrenched and insurgent forces within the union movement suggests that contemporary labour struggle combines so much of what has been considered "old" and "new" that the distinction has become untenable.

\section{Labour and Social Movement Organizations}

Two features of the union movement and the system of collective bargaining in the US distinguish the labour movement from other social movements. Firstly, the absence of a labour party in the US with mass working class support and institutional ties to the trade union movement is one of the most glaring examples of American exceptionalism. This means that the organizations, the SMOs of the labour movement, are largely limited to unions 
and labour confederations like the AFL-CIO and, since 2006, Change to Win. Living wage campaigns involve both unionized and non-unionized activists and are loosely affiliated with unions, giving them some independence from the officialdom, but they tend to be small. Given the steady decline of the percentage of the unionized workforce in the US (currently around 11\% as opposed to $35 \%$ following WWII), the unions, and therefore the labour movement, directly represent only a small minority of U.S. workers. This too cuts across class identity as it suggests that unions represent occupational groups rather than the working class as a whole.

In other countries, Labour, Socialist, and Communist parties have claimed to represent and have been seen as representing the working class, although their neo-liberal turn in recent years has compromised their legitimacy in the eye of many working class voters. Secondly, while other social movements usually involve a plethora of SMOs (think NAACP, Student Nonviolent Coordinating Committee, Southern Christian Leadership Conference, etc.), giving these movements a pluralistic character and allowing new elements to challenge older, entrenched leaderships through the establishment of new SMOs, the institutional structures connected to the collective bargaining machinery set up following the enactment of the NLRA limit the emergence of new SMOs in the labour movement. Collective bargaining agreements posit specific unions as bargaining agents, which sharply limits the ability of insurgents to challenge leaderships outside of the boundaries of the organizations controlled by incumbents. The labour movement, therefore, has fewer SMOs than the civil rights and other movements, which makes it more difficult to challenge entrenched leaderships. The Wisconsin Uprising produced an independent SMO, the Wisconsin Wave, founded in January, 2011. However, this organization is outside of the labour movement itself and, while working against the Walker measures, does not constitute a rankand-file effort to challenge the union officialdom in their own organizations or replace the current leadership with a more militant leadership. With no reform current or caucus challenging the teachers' union, the National Education Association (NEA) grew out of the movement in spite of the dissatisfaction with the current leadership. However, the Wisconsin Wave helped organize an ultimately unsuccessful recall election against Governor Walker. But the successful petition campaign to recall Walker (thus forcing new elections in which wealthy out-of-state conservative forces like the Koch brothers donated large sums to Walker's successful reelection campaign) involved thousands of union and non-union members who collected 900,000 signatures. In Chicago, however, the strike was led by a militant leadership. The leadership was itself the product of an impressive, long-term struggle by a militant, reform caucus, the Caucus of Reform Educators (CORE), that unseated a conservative old guard in 2010. Labour radicals, including organized socialists, played a key role in CORE's success (Bartlett, 2012).

These struggles, their democratic ethos, and rank-and-file, grassroots nature look much more like the social movements that served as models for the building of social movement theorizing and concept development from the 
1960s on than the post-war labour movement. Both the union and CORE were dynamic SMOs that led the movement. CORE was clearly an emergent SMO. Given its transformation under new leadership, the CTU can be considered emergent as well. Like the concepts old and new, the concepts "emerging" and "bureaucratized" are inadequate in and of themselves to capture the dynamism of some of the current developments in labour. In particular, the Madison and Chicago examples demonstrate how fresh rounds of mobilization occur both within and outside of existing SMOs. Existing structures both make possible and constrain the development of mass rank-and-file mobilization. Most of the hundreds of thousands of state employees and their allies who participated in the six weeks of marches and demonstrations in Madison and elsewhere throughout Wisconsin had never participated in such actions and were not in any way part of the union bureaucracy. Most had never participated in union activity before. They participated as union members in the Madison protests even before the union bureaucracy took over the movement. Missing from the Wisconsin uprising was rank and file control of the course of the movement. The bureaucracy assumed and retained control of the strike. It refused to entertain the possibility of a general strike, even though some locals endorsed this idea. The movement, therefore, displayed both aspects of an emerging social movement with its dynamism and spontaneity, as well as, on the organizational plane, a classic bureaucratized, routinized social movement organization.

\section{Emergent and Routinized Social Movements}

"Emergent" and "routinized" are general concepts within social movement literature that seek to broadly characterize movements in terms of their distance from formal political participation and also their dynamism and level of rank-and-file activism. The labour movement both historically and currently invites us to consider these concepts more closely. Some labour scholars have noted the conservatizing influence of organized unions with substantial paid bureaucracies in stifling rank-and-file activism, while the general wisdom of resource mobilization is that organizations and material resources are necessary to social movement development. But does the distinction between emergent and routinized unions always describe unions during periods of upheaval? The Chicago teachers strike was led by a militant leadership, responsive to the rank and file. This leadership was itself the product of a successful rank-and-file reform movement, the Caucus of Reform Educators (CORE), that unseated an entrenched union bureaucracy that had long made the Chicago Teachers Union the embodiment of the notion of a routine social movement organization. Thus a challenging organization (CORE) within a larger organization (the CTU) successfully overthrew the bureaucracy and assumed leadership of the union. Shortly thereafter, that leadership led a struggle that had all the hallmarks of a new social movement. Like the distinction between old and new social movements, the hybrid nature 
of contemporary labour struggles, in terms of the emergent and routinized trope, demonstrates how the new labour movement challenges many of the assumptions of social movement literature. The other arenas of the current cycle of protest, particularly the Arab Spring and Occupy, obviously also present challenges to social movement wisdom.

Both the Wisconsin and Chicago movements suggest that public sector unionism has been the sector that may continue to produce some of the most important labour struggles in the US. Employers and conservative politicians and elected officials are clearly targeting public sector unions. The Wisconsin case as well as the passage of "right to work" legislation in Indiana and Michigan are the most obvious manifestations of this. The stunning victory of the Chicago teachers sends a signal to both other public sector unions and those that would crush them, that fighting back can be successful.

Both the government and private sector offensive against unions and resistance to that offensive can be expected to continue ${ }^{2}$. As they do, further innovations in the forms of protest and organization will continue to develop, presenting both challenges and opportunities for social movement literature to offer insights into these remarkable movements and the prodigious hopes they inspire.

\section{Notes}

1 The author wishes to thank Michael Hanagan (History, Vassar College) and the anonymous reviewer for Studies in Social Justice for their insightful comments on an earlier draft of this article.

2 A decision expected in the spring or summer of 2014 by the US Supreme Court in Harris v. Quinn could extend "right to work" legislation, currently in force in twentyfour states, to all fifty states.

\section{References}

Bartlett, R. (2012). Chicago teachers' strike looms: Going head to head with mayor "1\%." Against the Current. May-June.

Bradbury, A., Brenner, M., Brown, J., Slaughter, J. \& Winslow, S. (2014). How to jump-start your union: Lessons from the Chicago teachers. Detroit: Labour Notes.

Brenner, A., Brenner, R. \& Winslow, C. (Eds.). (2010). Rebel rank and file. New York: Verso.

Brenner, M. (2013). Reform rekindled. Labor Notes, 410.

Buechler, S. (2011). Understanding social movements. Paradigm Publishers: Boulder.

Buhle, M. \& Buhle, P. (Eds.). (2011). It started in Wisconsin. New York: Verso.

Calhoun, C. (1993). "New social movements" of the early nineteenth century. Social Science History, 17(3), 385-427.

Dobbs, F. (1977). Teamster bureaucracy. New York: Monad.

DRUM (newsletter), (1968). Volume 1, Number 2.

Eggert, N. \& Guigni, M. (2012). The homogenization of "old" and "new" social movements: a comparison of participants in May Day and climate change demonstrations. Mobilization, 17(3).

Fantasia, R. \& Stepan-Norris, J. (2004). The Labor Movement in Motion. In D. Snow, S. A. Soule, \& H. Kriesi (Eds.), The Blackwell Companion to Social Movements. Malden, MA: Blackwell.

Fantasia, R. \& Voss, K. (2004). Hard Work. University of California Press: Berkeley. 
Geschwender, J. (1977) Class, race, and worker insurgency: The league of revolutionary Black workers. Cambridge: Cambridge University Press.

Glaberman, M. (1969) Dodge Revolutionary Union Movement. International Socialism (1st series), No. 36, April/May 1969.

Gorz, A. (1980) Farewell to the Working Class. New York: Pluto Press.

Hartshorn, I. (2013). Labor unions under attack in Morsi's Egypt._http://muftah.org/laborunions-under-attack-in-morsis-egypt/

Jones, G. (1983). Languages of class: Studies in English working class history, 1832-1982. Cambridge: Cambridge University Press.

Mann. K. (2011) A revival of labor and social protest research in France: Recent scholarship on May 1968. International Labor and Working Class History, 80, 203-214.

McAdam, D. (1998). Freedom Summer. Oxford: Oxford University Press.

Meyer, S. (1992). "Stalin over Wisconsin": The making and unmaking of militant unionism, 1900-1950. New Jersey: Rutgers University Press.

Needleman, R. (2003) Black freedom fighters in steel: The struggle for democratic unionism.

Piven, F. F. \& Cloward, R. (1977). Poor people's movements. New York: Vintage.

Preis. A. (1972). Labor's giant step: Twenty years of the CIO, 1936-1955. New York: Pathfinder Press.

Scott, J. (1988). Gender and the politics of history. New York: Columbia University Press.

Shaw, R. (2010). Beyond the fields: Cesar Chavez, the UFW, and the struggle for justice in the 21st century. Berkeley, CA: University of California at Berkeley Press.

Tarrow, S. (1994) Power in movement. Cambridge: Cambridge University Press.

Tilly, C. \& Wood, L. J. (2009). Social movements: 1768-2008. Boulder: Paradigm.

Touraine, A. (1971). The Post-Industrial Society. Tomorrow's Social History: Classes, Conflicts and Culture in the Programmed Society. New York: Random House.

Vigna, X. (2007) L'insubordination ouvrière dans les années 68: Essai d'histoire politique des usines, Rennes: Presses Universitaires de Rennes.

Wievorka, M. (2012). The resurgence of social movements. Journal of Conflictology, 3(2), $13-19$.

Yates, M. D. (Ed.). (2010). Wisconsin uprising: Labor fights back. New York: Monthly Review Press. 